\title{
LA-UR-20-21967
}

Approved for public release; distribution is unlimited.

Title: $\quad 2019$ Novel Coronavirus (COVID-19)

Author(s): $\quad$ Pasqualoni, Sara Elizabeth

Intended for: provide LANL presentation slides to DOE Headquarters

Issued: 2020-02-28 
Disclaimer:

Los Alamos National Laboratory, an affirmative action/equal opportunity employer, is operated by Triad National Security, LLC for the National Nuclear Security Administration of U.S. Department of Energy under contract 89233218CNA000001. By approving this article, the publisher recognizes that the U.S. Government retains nonexclusive, royalty-free license to publish or reproduce the published form of this contribution, or to allow others to do so, for U.S. Government purposes. Los Alamos National Laboratory requests that the publisher identify this article as work performed under the auspices of the U.S. Department of Energy. Los Alamos National Laboratory strongly supports academic freedom and a researcher's right to publish; as an institution, however, the Laboratory does not endorse the viewpoint of a publication or guarantee its technical correctness. 


\section{Novel Coronavirus (COVID-19)}

\section{Sara Pasqualoni MD MPH}

February 27, 2020

NATIONAL LABORATORY 


\section{What is 2019 Novel Coronavirus (COVID-19)?}

- Coronavirus is a family of common viruses, some causing illness in people and others that circulate among animals, including camels, cats and bats. Analysis of the genetic tree of this virus is ongoing to know the specific source of the virus. SARS, another coronavirus that emerged to infect people, came from civet cats, while MERS, another coronavirus that emerged to infect people, came from camels.

- A novel coronavirus is a virus that has not previously been identified.

- The first infection was reported in Wuhan, China in Dec. 2019, with a source probably originating from a livestock market, and a suspected origination from bats.

- Learn about 2019 Novel Coronavirus. 


\section{What is a pandemic?}

WHO: worldwide spread of a new disease

- Novel virus so little herd immunity

- Easily spread

- Healthy people may also be at risk for serious complications

- Healthcare system may become overwhelmed and alternate care sites may be designated

- Stockpiles may not meet vaccination and/or pharmaceutical needs

- Mortality rate high

- Public impacts such as travel restrictions, school or business closings

- Potential for severe impact on domestic and world economies

\section{INTER-PANDEMIC P ERIOD}

No new influenza virus subtypes have been

detected in humans. An influenza virus subtype

1 that has caused human infection may be present in animals. If present in animals, the risk of human disease is considered to be low.

\begin{tabular}{l|l}
1 & $\begin{array}{l}\text { in animals. If present in animals, the risk of } \\
\text { human disease is considered to be low. }\end{array}$ \\
\hline 2 & $\begin{array}{l}\text { No new influenza virus subtypes have been } \\
\text { detected in humans. However, a circulating } \\
\text { animal influenza virus subtype poses a substantia } \\
\text { risk of human disease. }\end{array}$
\end{tabular}

\section{PANDEMIC ALERT PERIOD}

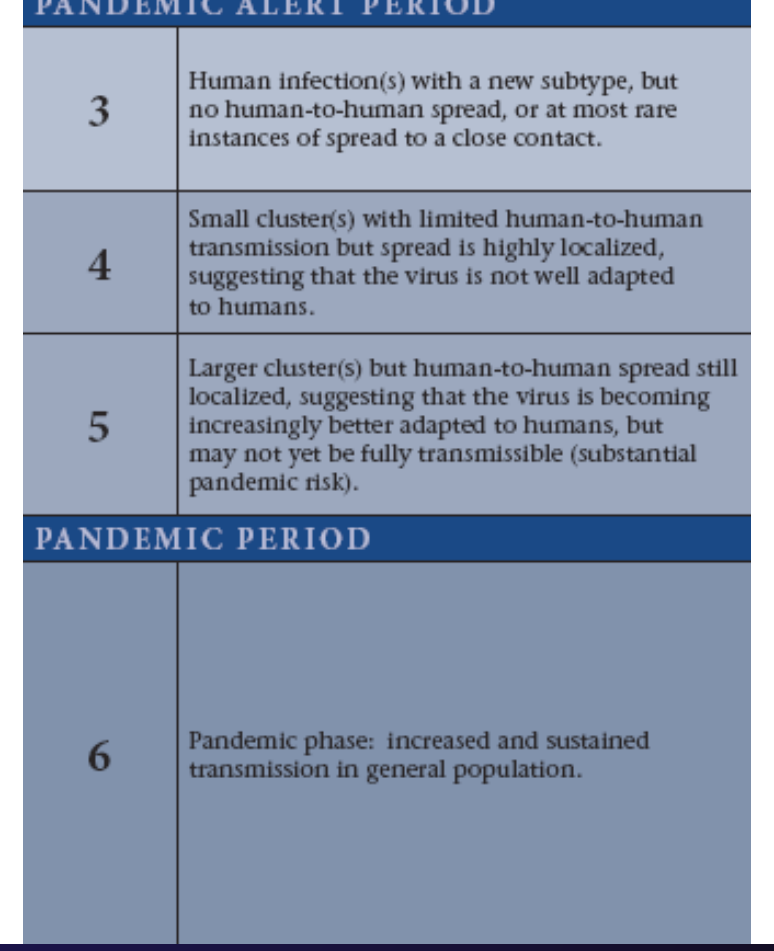




\section{Current Global Situation}

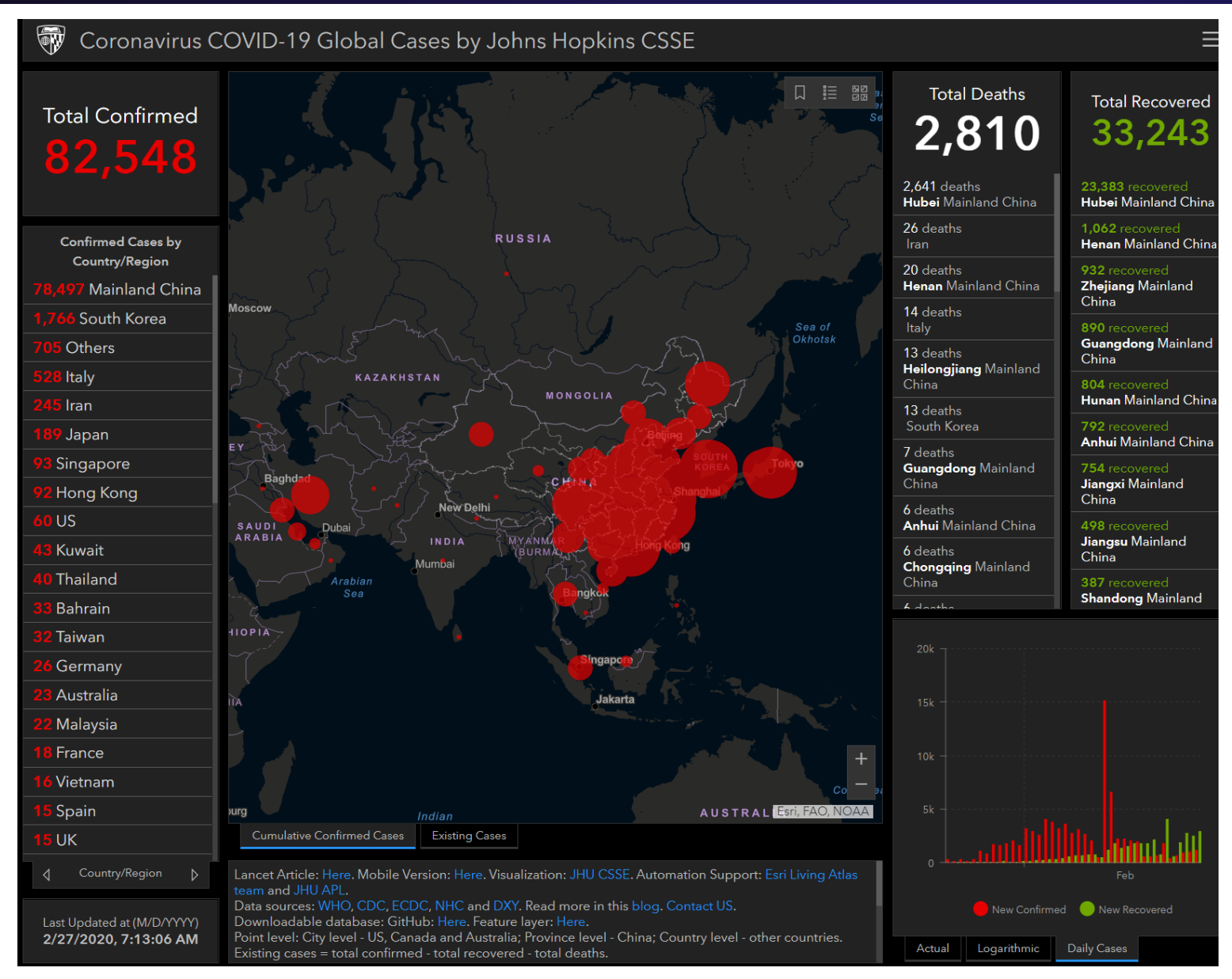

Distribution of cases worldwide

Other Countries: $4.93 \%(4,074$ cases $)$

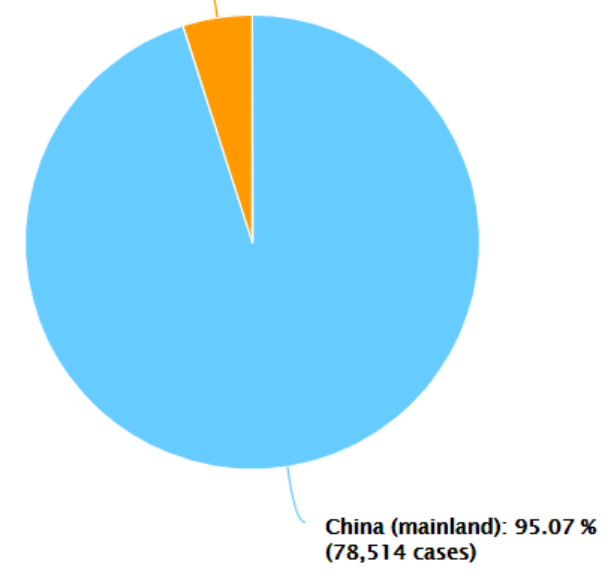




\section{Case Distribution outside China and CDC Travel Alerts}

\section{Warning Level 3}

CDC recommends that travelers avoid all nonessential travel to the following destinations:

- $\underline{\text { China Travel Health Notice }}$

- $\underline{\text { South Korea Travel Health Notice }}$

\section{Alert Level 2}

These destinations are experiencing sustained community transmission of respiratory illness caused by the novel coronavirus (COVID-19). The virus can spread from person to person. Older adults and those with chronic medical conditions should consider postponing nonessential travel.

$\underline{\text { Iran Travel Health Notice }}$

Italy Travel Health Notice

Japan Travel Health Notice

Watch Level 1

CDC does not recommend canceling or postponing travel to the following destinations. Travelers should practice usual precautions.

Hong Kong Travel Health Notice
Distribution of cases outside of mainland China

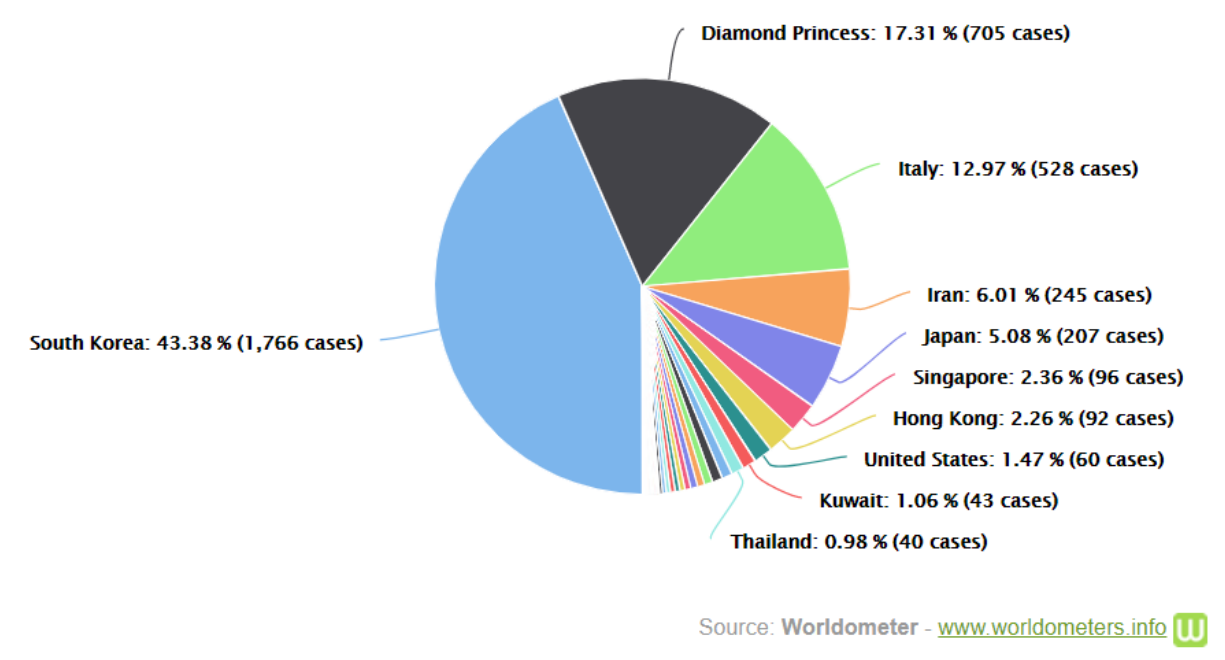




\section{New Case Incidence Rate}

\section{Daily Cases (worldwide)}

The spike observed on Feb. 12 is the result, for the most part, of a change in diagnosis classification for which 13,332 clinically (rather than laboratory) confirmed cases were all reported as new cases on Feb. 12 , even though they were diagnosed in the preceding days and weeks. We will distribute these cases over the correct period once the analysis being conducted by the WHO with China's NHC is completed. See also: How to interpret the $15,152(+600 \%)$ surge in new cases of February 12

$$
\text { Daily New Cases }
$$

Cases per Day
Data as of 0:00 GMT+0

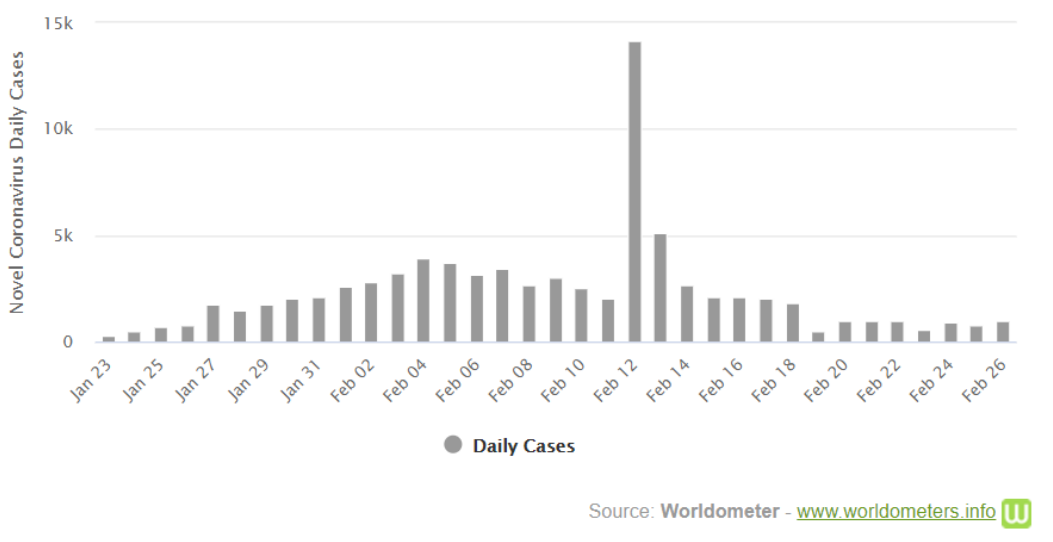

\section{Growth Factor of Daily New Cases}

Growth factor is the factor by which a quantity multiplies itself over time. The formula used is every day's new cases / new cases on the previous day. For example, a quantity growing by $7 \%$ every period (in this case daily) has a growth factor of 1.07 .

A growth factor above 1 indicates an increase, whereas one which remains between 0 and 1 it is a sign of decline, with the quantity eventually becoming zero, whereas a growth factor constantly above 1 could signal exponential growth

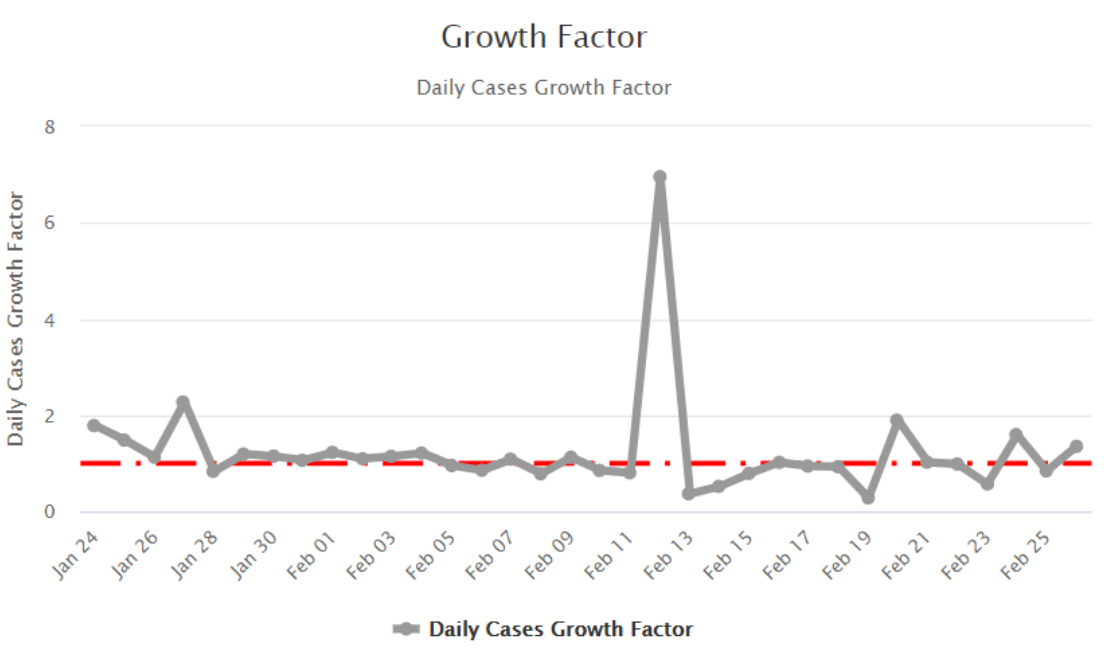




\section{Evolution of Case Severity}

Newly Infected vs. Newly Recovered

New Cases vs. New Recoveries

(Number of newly infected vs. number of recovered and discharged patients each day)

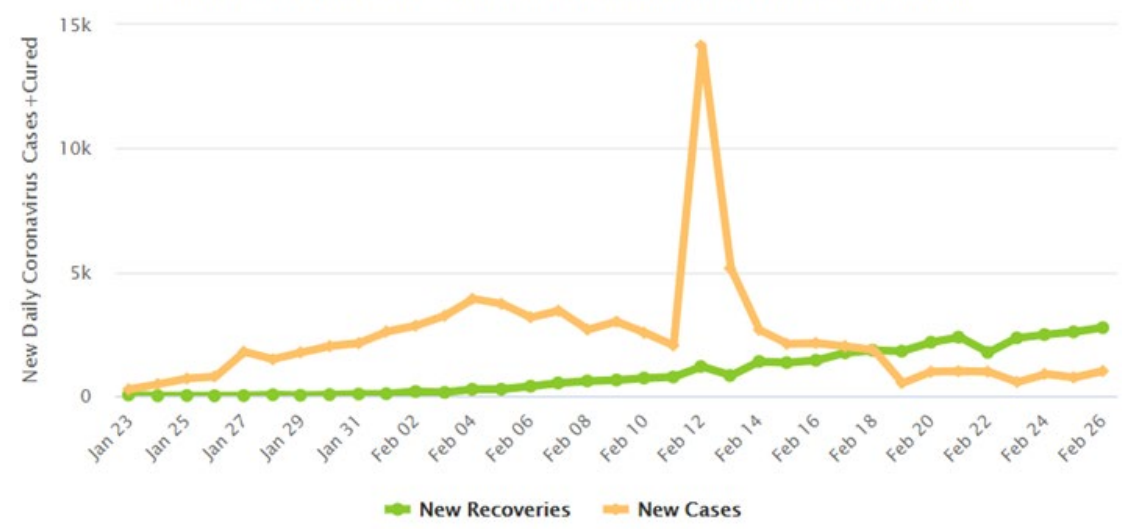

(idea by Rudi Roth) Source: Worldometer - www. worldometers. info W
Outcome of Cases (Recovery or Death)

Outcome of total closed cases (recovery rate vs death rate)

(Cumulative total deaths and recoveries over cumulative number of closed cases)

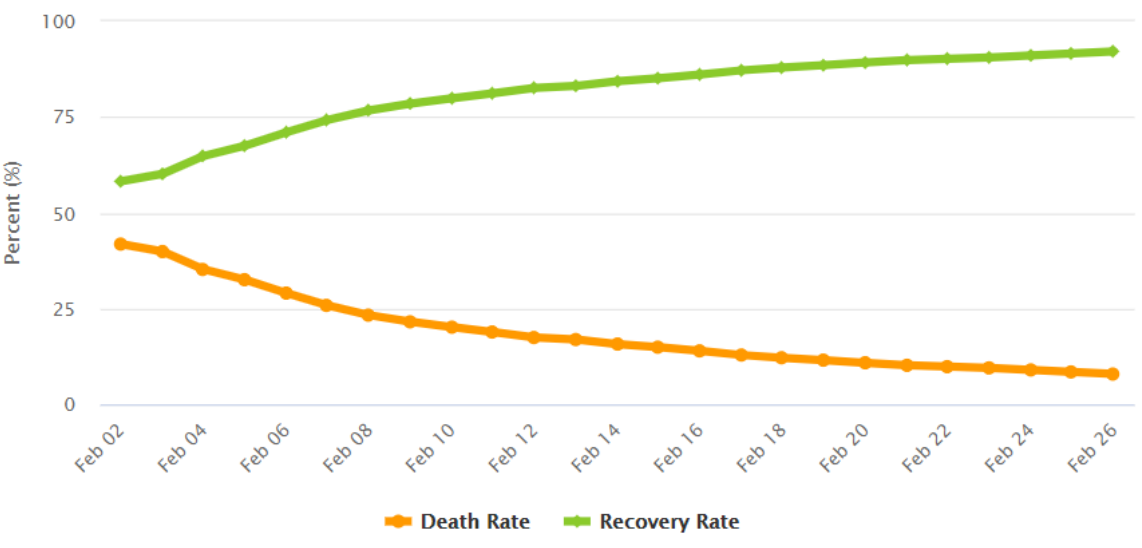

Source: Worldometer - www.worldometers.info $\boldsymbol{W}$ 


\section{Risk Assessment}

- Outbreaks of novel virus infections among people are always of public health concern. The risk from these outbreaks depends on characteristics of the virus, including how well it spreads between people, the severity of resulting illness, and the medical or other measures available to control the impact of the virus (for example, vaccine or treatment medications).

- The global public health threat posed by 2019-nCoV virus is high.

- For the general American public, who are unlikely to be exposed to this virus, the immediate health risk from 2019-nCoV is considered low at this time.

- Illness Severity

- Both MERS-CoV and SARS-CoV have been known to cause severe illness in people. The complete clinical picture with regard to COVID-19 is not fully understood. Reported illnesses have ranged from mild to severe, including illness resulting in death. Learn more about the symptoms associated with COVID-19.

- There are ongoing investigations to learn more. This is a rapidly evolving situation and information will be updated as it becomes available. 


\section{Current Trends and News of Interest}

- $\underline{C D C}$ has grown the COVID-19 virus in cell culture, which is necessary for further studies, including for additional genetic characterization. The cell-grown virus was sent to NIH's BEI Resources Repositoryexternal icon for use by the broad scientific community.

- DHHS has announced progress on vaccine development with human trials expected to begin in 6 weeks

- Progress made toward targeted antiviral therapy

- Studies looking at seasonality similary to influenza

- No treatment available-treatment is supportive

- Announcement of likelihood of global pandemic status have economic/Stock market impacts

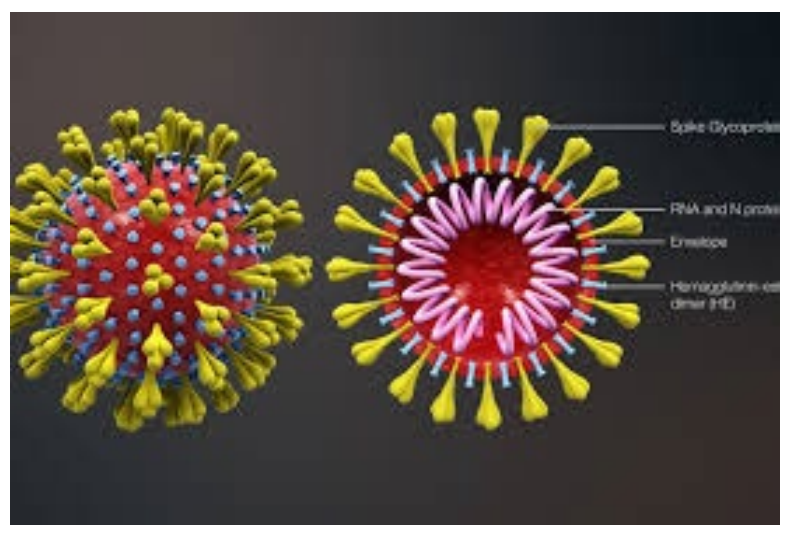




\section{What virus should I really be concerned about?}

CDC estimates* that, from October 1,2019 , through January 25,2020 , there have been:

$19,000,000-26,000,000$

flu illnesses

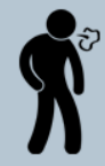

$180,000-310,000$

flu hospitalizations

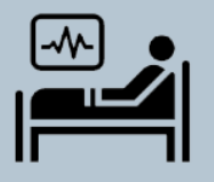

$8,600,000-12,000,000$

flu medical visits

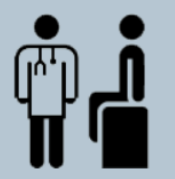

\section{$10,000-25,000$}

flu deaths

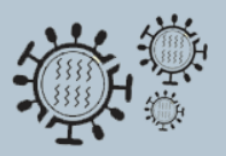

\section{Coronavirus Cases:}

82,588

view by country.

\section{Deaths:}

2,814

\section{Influenza in US}

Coronavirus globally

Influenza virus represents a common cause of pneumonia in the adult population, affecting 4-8\% of healthy adults. Rates have been 10-20\% during outbreaks and as high as 50\% during epidemics. Morbidity and mortality rates related to influenza pneumonia in both the general population and in selected groups (eg, patients with chronic diseases, the elderly) are substantial. 


\section{Mortality rate explained}

- Mortality rate to date is $2.4 \%$ of confirmed cases (there are likely mild cases and other cases not reported).

- $97 \%$ of the country's total deaths (414) were in the Hubei Province.

- Mortality rate in Wuhan was 4.9\%.

COVID-19 Fatality Rates by Age

- Mortality rate in other provinces was $\mathbf{0 . 1 6 \%}$.

- Lack of resources cited as a reason for high mortality rates (example that there were only 110 critical care beds in the three designated hospitals where most of the cases were sent).

- Mainly elderly, more than $80 \%$ are elderly over 60 years old, and more than $75 \%$ had underlying diseases present such as cardiovascular and cardiovascular diseases, diabetes and, in some cases, tumor.

- Comparison with other viruses:
- SARS
$9.6 \%$
- MERS
$34 \%$
- Avian Flu
$60 \%$
- Ebola
$90 \%$

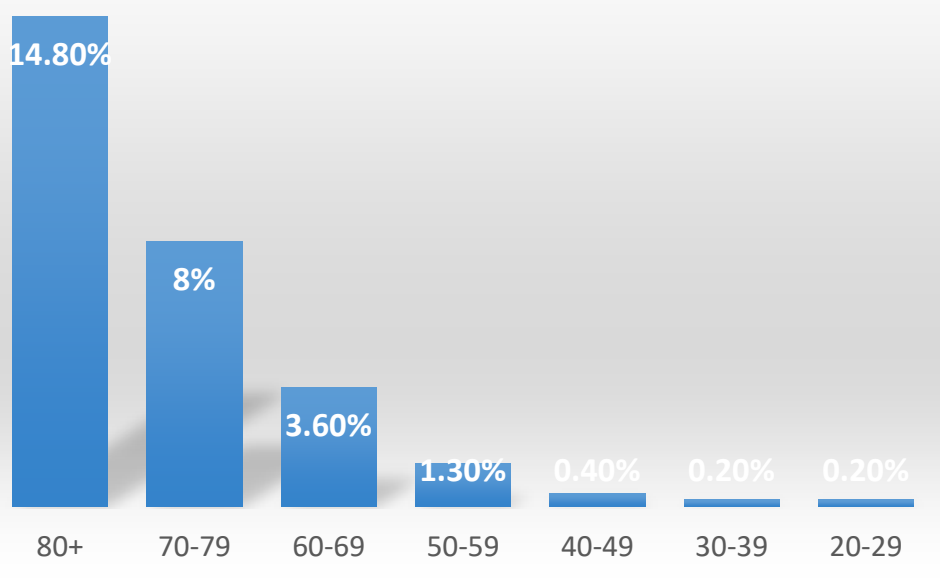




\section{What precautions can I take to protect myself?}

Preventing infections to coronavirus is similar to preventing infections to flu and the common cold.

- Most effective preventive measures for someone that is not sick:

- Frequent hand washing with soap and water for 20 seconds

- Avoid touching eyes, nose, mouth

- Avoid close contact with people that are sick (stay 6 feet away)

- Clean and disinfect frequently touched objects and surfaces

- The most effective preventive measure for someone that is sick:

- Stay home

- Avoid close contact with other family members

- Cover your cough or sneeze with a tissue and throw it in the trash

- Frequent hand washing 


\section{What about masks?}

- Masks do not protect you from coronavirus.

- It is very common in Asia for people to wear surgical masks. This gives the impression that there is evidence that a facemask protects you from respiratory infections.

- Unfortunately, science tells us otherwise. Wearing a surgical mask may diminish the chances of an infected person spreading their infection to others, but does not stop you from inhaling the small droplets that transmit influenza, most coronaviruses and other respiratory pathogens that easily come in around the mask when you inhale.

\section{WHEN TO USE A MASK}

For healthy people wear a mask only if you are taking care of a person with suspected 2019ncov infection

Wear a mask, if you are coughing or sneezing

Masks are effective only when used in combination with frequent hand-cleaning with alcohol-based hand rub or soap and water

If you wear a mask then you must know how to use it and dispose of it properly 


\section{What is LANL doing to protect the workforce}

- Activation of Pandemic Advisory Team (PAT)

- Active identification of new hires, travelers and visitors from high risk areas and management in accordance with CDC and other stakeholder guidance

- Partnerships with NMDOH, DOE BEMT and collaboration with DOE Site Medical Director's Council

- Communication, communication, communication

- Group discussions and education to mitigate anxieties

\begin{tabular}{|c|c|c|}
\hline Country & Travel To & LANL precautions \\
\hline China & Avoid Non-Essential & 14 day isolation \\
\hline South Korea & Avoid Non-Essential & $\begin{array}{l}\text { Clear through OM if fever, } \\
\text { cough or difficulty breathing }\end{array}$ \\
\hline Italy & $\begin{array}{l}\text { Older adults and those with chronic medical conditions } \\
\text { should consider postponing nonessential travel. } \\
\text { Travelers should avoid contact with sick people and clean } \\
\text { their hands often by washing with soap and water for at } \\
\text { least } 20 \text { seconds or using an alcohol-based hand sanitizer } \\
\text { with } 60 \%-95 \% \text { alcohol. }\end{array}$ & $\begin{array}{l}\text { Clear through OM if fever, } \\
\text { cough or difficulty breathing }\end{array}$ \\
\hline Japan & $\begin{array}{l}\text { Older adults and those with chronic medical conditions } \\
\text { should consider postponing nonessential travel. } \\
\text { Travelers should avoid contact with sick people and clean } \\
\text { their hands often by washing with soap and water for at } \\
\text { least } 20 \text { seconds or using an alcohol-based hand sanitizer } \\
\text { with } 60 \%-95 \% \text { alcohol. }\end{array}$ & $\begin{array}{l}\text { Clear through OM if fever, } \\
\text { cough or difficulty breathing }\end{array}$ \\
\hline Iran & $\begin{array}{l}\text { Older adults and those with chronic medical conditions } \\
\text { should consider postponing nonessential travel. } \\
\text { Travelers should avoid contact with sick people and clean } \\
\text { their hands often by washing with soap and water for at } \\
\text { least } 20 \text { seconds or using an alcohol-based hand sanitizer } \\
\text { with } 60 \%-95 \% \text { alcohol. }\end{array}$ & $\begin{array}{l}\text { Clear through OM if fever, } \\
\text { cough or difficulty breathing }\end{array}$ \\
\hline
\end{tabular}




\section{Infectious Disease/Pandemic Plan for LANL/NALA}

- An official LANL/NA-LA Infectious Disease/Pandemic Plan is in place (SEO-COOP-O01, R3.3) and in use.

- The LANL Medical Director is the chair of the Pandemic Advisory Team, and includes members from LANL, NALA, $E M L A$ and $N_{3} B$. The team includes Emergency Management, COOP, ALDESHOSS, Communications/Public Affairs, HR, General Counsel, and NIE leaders.

- Since the novel corona virus outbreak, the PAT team has met 3 times and integrated with DOE-HQ, NNSA-HQ, New Mexico State Department of Health, Los Alamos County, and other NNSA sites. The Medical Director is in regular communications with other Medical Directors throughout the DOE Complex and throughout the State of New Mexico

- PAT team decisions have been in line with Center for Disease Control recommendations and we have also benchmarked with SNL, ORNL, LLNL, INL, DOE-HO and WIPP

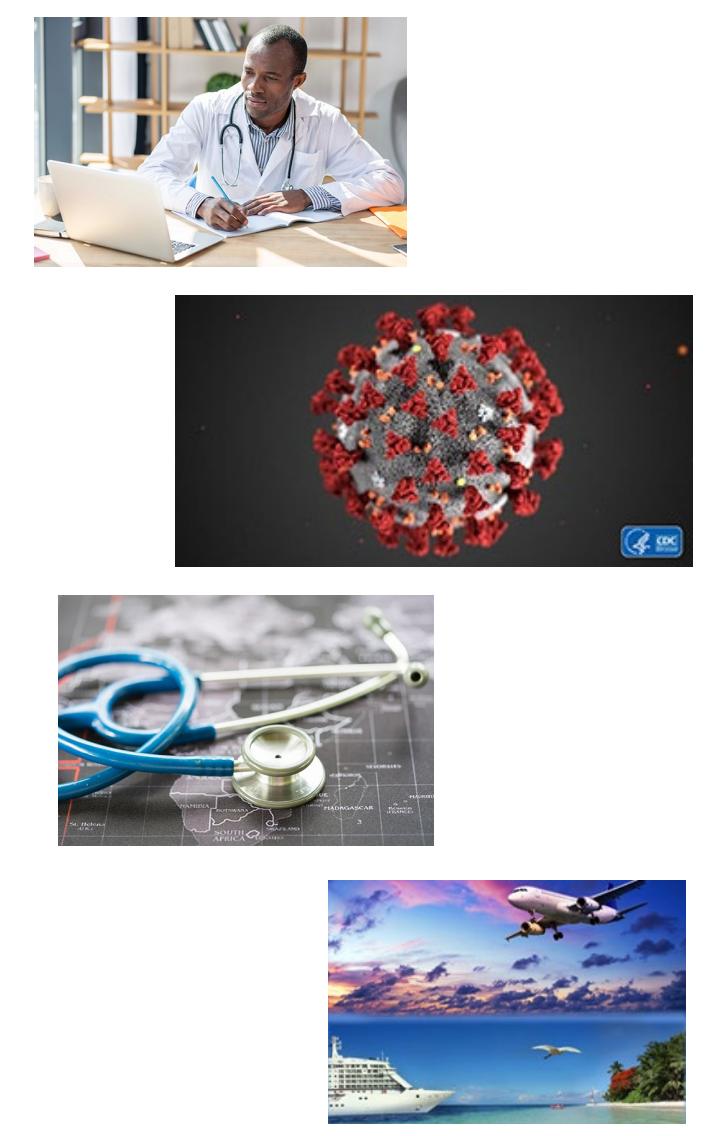




\section{LANL/NALA Infectious Disease/Pandemic Plan and Pandemic Advisory Team (PAT) matrix. On 1/30/20, LANL moved to MEDCON Level 2}

\begin{tabular}{|c|c|c|}
\hline $\begin{array}{l}\text { MEDCON } \\
\text { Level }\end{array}$ & $\begin{array}{l}\text { Description/ } \\
\text { Characteristics }\end{array}$ & Key actions \\
\hline 0 & $\begin{array}{l}\text { Normal conditions, no unusual } \\
\text { infectious disease threats }\end{array}$ & $\begin{array}{l}\text { - Validate documentation, annual meetings, monitor professional sources } \\
\text { - } \quad \text { Integrate with DOH, DOE, Community, DOH prior to flu season } \\
\text { Dril//Exercise, implement continuous improvement }\end{array}$ \\
\hline 1 & $\begin{array}{l}\text { Confirmed infectious disease } \\
\text { threat in the world }\end{array}$ & $\begin{array}{ll}\text { - } & \text { Monitor world-wide conditions, and LANL state of readiness } \\
\text { - } & \text { Integrate with DOH, DOE, Community, DOH, and LAMC } \\
\text { - } & \text { Communications plan implemented with leaders and workforce. }\end{array}$ \\
\hline 2 & $\begin{array}{l}\text { Disease outbreak outside of } \\
\text { continental US; sickening 100s- } \\
1000 \text { s with possible fatalities. } \\
\text { US cases quarantined. }\end{array}$ & $\begin{array}{l}\text { - } \quad \text { Monitor world-wide conditions, and LANL state of readiness } \\
\text { - } \quad \text { Reviegrate with DOH, DOE, Community, DOH, and LAMC } \\
\text { - } \quad \text { Communications plan implemented with leaders and workforce } \\
\text { PAT meets regularly, consider limiting travel. Validate HR policies, IT } \\
\text { capability for telework. } \\
\text { DOE Biological Event Monitoring Team (BEMT) integration. }\end{array}$ \\
\hline 3 & $\begin{array}{l}\text { Disease outbreak in North } \\
\text { America. Cluster outbreak in } \\
\text { US, no cluster in NM }\end{array}$ & $\begin{array}{l}\text { - Increase focus and frequency of all actions above. } \\
\text { - } \quad \text { WR/IT/Legal focus on telework policies/capabilities. } \\
\text { materials/resources. } \\
\text { - Work with Security to validate minimum staffing requriements. } \\
\text { - Coordinate with COOP to validate mission essential function staffing. } \\
\text { Communications plan increases contact, sets up information phone line } \\
\text { and web page }\end{array}$ \\
\hline
\end{tabular}




\section{LANL/NALA Infectious Disease/Pandemic Plan and Pandemic Advisory Team (PAT)}

\begin{tabular}{|c|c|c|}
\hline $\begin{array}{l}\text { MEDCON } \\
\text { Level }\end{array}$ & $\begin{array}{l}\text { Description/ } \\
\text { Characteristics }\end{array}$ & Key actions \\
\hline 4 & $\begin{array}{l}\text { Outbreak affects surrounding } \\
\text { communities and/or LA }(\sim 10- \\
20 \% \text { absenteeism directly } \\
\text { related.) Cluster outbreak in } \\
\text { local region. Symptoms similar } \\
\text { to influenza. Poses threat to } \\
\text { mission essential operations } \\
\text { minimum staffing. }\end{array}$ & $\begin{array}{l}\text { - Increase focus and frequency of all actions above. } \\
\text { - Coordinate communications with state \& local agencies and intensify } \\
\text { employee education/communications. } \\
\text { Increase travel restrictions, self-quarantine restrictions. } \\
\text { - With HR/Legal/IT increase telework capabilities. } \\
\text { Senior management determines mission essential personnel and } \\
\text { prioritization for resources. Make notifications to essential personnel as } \\
\text { appropriate. }\end{array}$ \\
\hline 5 & $\begin{array}{l}\text { Outbreak affects communities } \\
\text { and/or LA ( } 20-30 \% \\
\text { absenteeism directly related.) } \\
\text { Outbreak expanding. Ability to } \\
\text { cause severe symptoms. Poses } \\
\text { immediate threat to mission } \\
\text { essential operations and } \\
\text { minimum staffing }\end{array}$ & $\begin{array}{l}\text { - } \quad \text { Increase focus and frequency of all actions above. } \\
\text { - } \quad \text { Ensure distribution of disease appropriate vaccines, medications, and PPE } \\
\text { to essential workforce. } \\
\text { Roll out plan to utilize limited resources to ensure Continuity of Operations } \\
\text { for mission essential operations. } \\
\text { Follow plan/procedures for ongoing emergency event. }\end{array}$ \\
\hline 6 & $\begin{array}{l}\text { Pandemic situation - community } \\
\text { absenteeism } 30 \% \text { or higher. } \\
\text { Widespread pandemic } \\
\text { throughout US. High severity. } \\
\text { Activate COOP Plan. }\end{array}$ & $\begin{array}{l}\text { - Increase focus and frequency of all actions above. } \\
\text { - If needed, activate remote communications plan with workforce. } \\
\text { - Senior management determines whether to release non-essential } \\
\text { personnel, or rotation of personnel. Suspension of some operations. } \\
\text { Possible suspension of all operations, including mission essential functions. } \\
\text { Intensify efforts on communications, and distribution of disease appropriate } \\
\text { resources. }\end{array}$ \\
\hline
\end{tabular}




\section{Stigma Related to COVID-19}

- Fear and anxiety can lead to social stigma towards people from other countries.

- Stigma hurts everyone by creating more fear or anger towards ordinary people instead of the disease that is causing the problem. We can fight stigma and help not hurt others by providing social support. We can communicate the facts that being Chinese or Asian American does not increase the chance of getting or spreading COVID-19.

- Communicators and public health officials can help counter stigma during the COVID-19 response.

- Maintain privacy and confidentiality of those seeking health care and those who may be part of any contact investigation.

- Timely communication of the risk or lack of risk from associations with products, people, and places.

- Raise awareness about COVID-19 without increasing fear.

- Share accurate information about how the virus spreads.

- Speak out against negative behaviors, including negative statements on social media about groups of people, or exclusion of people who pose no risk from regular activities.

- Be cautious about the images that are shared. Make sure they do not reinforce stereotypes.

- Engage with stigmatized groups in person and through media channels including news media and social media.

- Share the need for social support for people who have returned from China or are worried about friends or relatives in the affected region. 


\section{Where can I learn more?}

General information--

- Center for Disease Control and Prevention

- New Mexico Department of Health

- U.S. Department of State

WHO Dashboard--

- http://who.maps.arcgis.com/apps/opsdashboard/index.htm|\#/c88e37cfc43b4ed3bafg77d77e4ao $\underline{667}$

CDC recommendations updated 2/5/2020--

- https://www.cdc.gov/coronavirus/2019-ncov/php/risk-assessment.html Additionally, the following Laboratory offices are available should you need more information on the issued Laboratory guidance--

- Office of Counterintelligence

- Foreign Travel Office

- Occupational Medicine 